\title{
Protoplast and Cytoplasmic Membrane Preparations from Streptococcus sanguis and Streptococcus mutans
}

\author{
By MARIE SCHÖLLER, * J. PAUL KLEIN, PASCAL SOMMER AND \\ ROBERT FRANK \\ Unité de Recherches, INSERM U157, Faculté de Chirurgie Dentaire, 67000 Strasbourg, France
}

(Received 30 November 1982; revised 3 May 1983)

\begin{abstract}
Protoplasts were prepared from Streptococcus sanguis and some $S$. mutans serotypes by use of lysozyme (EC 3.2.1.17) under particular conditions: cells had to be grown in DL-threonine (20 mM) and harvested in early exponential phase. The efficiency of protoplast formation was enhanced by two additional steps: plasmolysis (in 12\% PEG), prior to addition of lysozyme, and a swirling phase, after the enzymic action. This procedure allowed us to obtain clean protoplasts, with only $0.5 \%$ contamination by bacterial cell walls. Up to $90 \%$ protoplast lysis was obtained in $0.5 \mathrm{M}-\mathrm{NaCl}$. Cytoplasmic membrane purification was achieved by centrifugation on a glycerol cushion.
\end{abstract}

\section{INTRODUCTION}

Streptococcus sanguis and Streptococcus mutans are commonly associated with dental caries (Guggenheim, 1968). The latter species appears to be very heterogeneous, and has been divided into five biotypes (Shklair \& Keene, 1976), four genetic groups (Coykendall, 1974) and eight ( $a$ to $h$ ) serological groups (Bratthall, 1970; Perch et al., 1974; Beighton et al., 1981). Since purified serotype antigens were proposed as possible vaccines against dental caries (Taubman, 1973) much attention has been given to those characterized as wall-associated polysaccharides containing, in some cases, lipoteichoic acid (Silvestri et al., 1978; Vaught \& Bleiweis, 1974). Because of the poor cross-reactivity between the different serotypes, more recent studies have dealt with the characterization of extracellular or wall-associated proteins (Russell \& Lehner, 1978; Russell, 1979; Schöller et al., 1981). The difficulty in obtaining pure plasma membranes, free of cell wall components, from $S$. mutans and $S$. sanguis stems from the lack of efficient methods of protoplast preparation. Hence their cytoplasmic membranes are poorly characterized. Spheroplast induction with phage-associated lysins has been described for streptococci of Lancefield groups A, C, D and H (Krause, 1972; Bleiweis \& Zimmermann, 1961; Calandra et al., 1975), but not for oral streptococci. Except for those belonging to Lancefield group D, most streptococci are very resistant to lysozyme lysis (Smith, 1973).

Lysozyme ( $N$-acetylmuramidase, EC 3.2.1.17) exerts its lytic effect through hydrolysis of specific glycosidic linkages in its substrate, the peptidoglycan of the bacterial cell wall. Streptococci, and especially strains of $S$. mutans and $S$. sanguis, are considered refractory to lysozyme action (Gibbons et al., 1966) and few studies have shown lysis of $S$. mutans cell walls with the enzyme alone (Coleman et al., 1970). Bacterial resistance to lysozyme may stem fror. several factors including the three-dimensional structure of peptidoglycan (Chiu et al., 1974; Formanek et al., 1974), the presence of teichoic acids covalently bound to peptidoglycan (Joseph \& Shockman, 1975; Markham et al., 1975), the presence of unacetylated glucosamine residues in peptidoglycan (Hayashi et al., 1973) and surface adsorption of macromolecules from growth media (Chassy, 1976). Procedures used to enhance sensitivity to lysozyme include use of

Abbreviations: DAP, diaminopimelic acid; PEG, polyethylene glycol. 
appropriate culture media and age of culture, and the addition of high concentrations of sucrose, detergents and salts (Coleman et al., 1970; Eisenberg \& Lillmars, 1975; Chassy, 1976; Pollock et al., 1976; Shockman et al., 1979; Goodman et al., 1981). Thus, lysozyme can reach and degrade the murein layer after acetylation of cell wall muramic acid residues in exponential phase cultures of streptococci (Eisenberg \& Lillmars, 1975), or by inclusion of DL-threonine in culture media, which interferes with cell wall cross-linking in $S$. mutans by a penicillin-like inhibition of lysine incorporation (Chassy, 1976). Destabilization of cell wall can also be achieved by resuspending cells in dilute Tris/ $\mathrm{HCl}$ buffer supplemented with high concentrations of sucrose or polyethylene glycol (PEG), and by adding lysozyme in considerable excess relative to total cell peptidoglycan (Witholt \& Boekhout, 1978; Owen \& Freer, 1972; Johnston \& Gotschlich, 1974). Although all these procedures were effective in the lysis of $S$. sanguis and $S$. mutans cells, no satisfactory method for conversion of these bacteria into stable protoplasts with lysozyme has yet been described.

Owen \& Freer (1972) showed the efficiency of whole-cell plasmolysis, before removal of cell wall with lysozyme, for the preparation of mesosomal and cytoplasmic membranes from Micrococcus lysodeikticus. We tested the effect of such treatment for the preparation of stable protoplasts from $S$. sanguis and $S$. mutans strains representative of each of Bratthall's serological groups. The present paper describes a method for preparation of cytoplasmic membranes from protoplasts of $S$. sanguis OMZ9 and different $S$. mutans serotypes.

\section{METHODS}

Bacteria and growth conditions. Streptococcus sanguis OMZ9 was used as a reference strain throughout this study. The following $S$. mutans serotypes were used: OMZ51 (b), OMZ70 (c), OMZ176 (d), B-2 (e), OMZ175 (f). The origin and maintenance of all strains were described by Schöller et al. (1981).

Cells of $S$. sanguis used for conversion to protoplasts were grown in Brain Heart Infusion Broth (BHI, Difco) supplemented with $20 \mathrm{mM}$-DL-threonine at $37^{\circ} \mathrm{C}$ (Chassy, 1976). The bacteria were harvested by centrifugation $\left(5000 \mathrm{~g}, 20 \mathrm{~min}, 4^{\circ} \mathrm{C}\right)$ in mid-exponential phase $\left(\mathrm{OD}_{540}=1.0\right)$ and washed twice in $10 \mathrm{~mm}$-Tris $/ \mathrm{HCl}$ buffer $\mathrm{pH} 7 \cdot 2$ (referred to as 'Tris-buffer' throughout this paper) before use as described below.

The efficiency of protoplast formation was monitored by measuring the cell-associated peptidoglycan and DNA at each step of the preparation. meso-Diamino[G- $\left.{ }^{3} \mathrm{H}\right]$ pimelic acid $\left(\left[{ }^{3} \mathrm{H}\right] \mathrm{DAP}\right)$ was employed to label peptidoglycan in vivo. Cells of $S$. sanguis OMZ9, grown as previously described, were transferred into $100 \mathrm{ml}$ BHI containing $\left[{ }^{3} \mathrm{H}\right] \mathrm{DAP}\left(25 \mathrm{mM} ; 4 \mathrm{Ci} \mathrm{mmol}^{-1} ; 148 \mathrm{GBq} \mathrm{mmol}^{-1}\right)$, and allowed to grow for three mean generation times. DNA was labelled with $\left[{ }^{3} \mathrm{H}\right]$ thymidine by growing bacteria as above, in $100 \mathrm{ml} \mathrm{BHI}$ supplemented with DLthreonine $(20 \mathrm{mM})$, deoxyadenosine $(20 \mu \mathrm{M})$ and $\left[\right.$ methyl $\left.^{-3} \mathrm{H}\right]$ thymidine $\left(0.5 \mu \mathrm{M} ; 2 \mathrm{Ci} \mathrm{mmol}^{-1} ; 74 \mathrm{GBq} \mathrm{mmol}^{-1}\right)$. Labelled cells were harvested in mid-exponential phase and used for protoplast formation.

Protoplast formation. Washed cells were resuspended to one-tenth of the culture volume in Tris-buffer containing $6 \%(\mathrm{w} / \mathrm{v})$ PEG 4000. Lysozyme was added to final concentrations between 125 and $1000 \mu \mathrm{g}$ per $\mathrm{ml}$ of initial culture volume, and the suspensions were incubated for $1 \mathrm{~h}$ at $30^{\circ} \mathrm{C}$.

Optimal PEG concentration for protoplast stability was determined by suspending protoplasts for $24 \mathrm{~h}$ in Trisbuffer containing various PEG concentrations.

In the procedure involving plasmolysis and swirling, washed cells were allowed to equilibrate for $2 \mathrm{~h}$ at $30^{\circ} \mathrm{C}$ in Tris-buffer containing $12 \%$ PEG. After lysozyme treatment, the suspension was made $6 \%$ with respect to PEG, and subjected to swirling (100 r.p.m.) at $30^{\circ} \mathrm{C}$ for $1 \mathrm{~h}$.

Preparation of membranes. Protoplasts were sedimented from the suspending medium by centrifugation $(8000 \mathrm{~g}$, $\left.20 \mathrm{~min}, 4^{\circ} \mathrm{C}\right)$, washed twice with Tris-buffer containing $6 \%$ PEG and resuspended $\left(2 \mathrm{~h}, 30^{\circ} \mathrm{C}\right)$ in $10 \mathrm{ml}$ Trisbuffer with or without $15 \%$ PEG. In both cases lysis was performed in one of four ways: (i) sonication, (ii) freezethawing procedures, (iii) osmotic shock (addition of $0.5 \mathrm{M}-\mathrm{NaCl}$ to Tris-buffer or resuspension of protoplasts in $1 \mathrm{M}$-phosphate buffer $\mathrm{pH} 7 \cdot 2)$, and (iv) treatment with SDS ( $2 \%, \mathrm{w} / \mathrm{v})$.

Lysates were centrifuged three times at $6000 \mathrm{~g}$ for $20 \mathrm{~min}$ at $4{ }^{\circ} \mathrm{C}$ to remove any residual protoplasts or bacteria. The $6000 \mathrm{~g}$ supernatant, after $15 \mathrm{~min}$ treatment with DNAase $\left(10 \mu \mathrm{g} \mathrm{ml}^{-1}\right)$ and RNAase $\left(10 \mu \mathrm{g} \mathrm{ml}^{-1}\right)$, was centrifuged at $200000 \mathrm{~g}$ for $30 \mathrm{~min}$ at $4{ }^{\circ} \mathrm{C}$. The membrane pellet was washed twice, resuspended in Tris-buffer and layered on a glycerol cushion. Centrifugation was carried out in an $S W-25$ rotor at $40000 \mathrm{~g}$ for $60 \mathrm{~min}$ at $4{ }^{\circ} \mathrm{C}$. The upper aqueous phase was carefully removed and centrifuged $\left(200000 \mathrm{~g}, 30 \mathrm{~min}, 4^{\circ} \mathrm{C}\right)$, and the sedimented membranes were washed three times with Tris-buffer and stored as a thick suspension at $-20^{\circ} \mathrm{C}$.

Monitoring procedures. The efficiency of protoplast formation was assessed by monitoring the extent of $\left[{ }^{3} \mathrm{H}\right.$ ]DAP labelling of cells at each stage of the procedure. Samples $(1 \mathrm{ml})$ were collected on membrane filters (pore size $0.22 \mu \mathrm{m}$, Millipore) and immediately precipitated with $10 \%(\mathrm{w} / \mathrm{v})$ cold TCA. The dried filters were 
transferred to glass vials containing toluene supplemented with PPO $(0.5 \%, w / v)$ and POPOP $(0.01 \%$,w/v) before counting in an SL-32 liquid scintillation counter (Intertechnique).

Protoplast integrity was assessed by measuring non-sedimentable TCA-precipitable $\left[{ }^{3} \mathrm{H}\right]$ thymidine radioactivity of incubation mixtures. Samples $(10$ to $30 \mu \mathrm{l})$ were spotted on $3 \mathrm{MM}$ Whatman filters, precipitated with $10 \%$ TCA and counted as previously described. Protoplast leakage was determined by measuring TCAprecipitable $\left[{ }^{3} \mathrm{H}\right]$ thymidine radioactivity released into the supernatant fraction of sedimented incubation mixtures. Purity of membrane preparations was evaluated by counting residual TCA-precipitable $\left[{ }^{3} \mathrm{H}\right] \mathrm{DAP}$ and $\left[{ }^{3} \mathrm{H}\right]$ thymidine label present in membrane suspensions.

The different steps in protoplast and membrane preparations were also followed by electron microscopy. Protoplast pellets were fixed for $2 \mathrm{~h}$ in a mixture of $2 \%(\mathrm{v} / \mathrm{v})$ paraformaldehyde and $2 \%(\mathrm{v} / \mathrm{v})$ glutaraldehyde in $0.1 \mathrm{M}$-cacodylate buffer $(\mathrm{pH} 7.4)$, washed with cacodylate buffer and postfixed in $1 \%(\mathrm{w} / \mathrm{v})$ osmium tetroxide for $1 \mathrm{~h}$, dehydrated with ethanol and embedded in Epon. Membrane preparations after osmium tetroxide postfixation were first embedded in $1 \%(w / v)$ agar, before dehydration and embedding in Epon.

Analytical procedures. Protein was determined by a modified Lowry method (Dulley \& Grieve, 1975), with bovine serum albumin as standard, in the presence of $2 \%(\mathrm{w} / \mathrm{v}) \mathrm{SDS}$. Total hexose was estimated with the anthrone reagent, with glucose as standard (Morris, 1948). DNA was determined by the fluorimetric method of Thomas \& Farquhar (1978), with calf thymus DNA as standard. Total lipid was extracted according to Osborn $e$ al. (1972) and the phosphorus concentration measured according to Baginsky \& Zak (1960).

Enzyme assays. Adenosine-5'-triphosphatase (ATPase, EC 3.6.1.3) was analysed by the method of Abrams (1965) on freshly isolated membranes. The released inorganic phosphate from ATP was measured by the procedure of Baginsky \& Zak (1960). The reaction mixture $(1 \mathrm{ml})$ contained $50 \mathrm{mM}-\mathrm{Tris} / \mathrm{HCl}$ buffer, $\mathrm{pH} 7 \cdot 2$, $5 \mathrm{mM}-\mathrm{MgCl}_{2}, 5 \mathrm{mM}$-ATP and the fraction to be tested. Glucose-6-phosphate dehydrogenase (EC 1.1.1.49) activity was measured by following the increase in absorption at $340 \mathrm{~nm}$ resulting from the glucose 6-phosphate dependent reduction of NADP. The assay $(1 \mathrm{ml})$ contained $100 \mathrm{~mm}$-Tris/ $/ \mathrm{HCl}$ buffer $\mathrm{pH} 7.5,2$ mM-disodium glucose 6-phosphate, $0 \cdot 25 \mathrm{mM}-\mathrm{NADP}$ and the fraction to be tested.

\section{RESULTS}

Protoplast formation. The susceptibility of $S$. sanguis OMZ9 to different lysozyme concentrations, under various conditions, was assayed by measuring the residual $\left[{ }^{3} \mathrm{H}\right] \mathrm{DAP}$ contained in protoplasts. Incubation of $S$. sanguis suspensions with 500 to $1000 \mu \mathrm{g}$ lysozyme $\mathrm{ml}^{-1}$ for $1 \mathrm{~h}$ resulted in a loss of $85 \%$ of the $\left[{ }^{3} \mathrm{H}\right] \mathrm{DAP}$ label (Fig. 1). Plasmolysis for $2 \mathrm{~h}$ in Tris-buffer containing $12 \%$ PEG before lysozyme treatment allowed an additional loss of [ $\left.{ }^{3} \mathrm{H}\right] \mathrm{DAP}$ of $10 \%$ (Fig. 1). When a swirling step $(1 \mathrm{~h})$ in Tris-buffer containing $6 \%$ PEG followed plasmolysis and lysozyme treatment, only $1.45 \%$ of the $\left[{ }^{3} \mathrm{H}\right]$ DAP remained sedimentable (Fig. 1, Table 1 ).

PEG concentration was chosen after assessing the effect upon protoplast stability of various concentrations ( 4 to $12 \%$ ) in Tris-buffer, after $24 \mathrm{~h}$ incubation of cell suspensions obtained by a $1 \mathrm{~h}$ treatment with lysozyme $\left(500 \mu \mathrm{g} \mathrm{ml}^{-1}\right)$. A $6 \%$ PEG concentration gave minimal lysis and was employed during enzymic digestion and swirling, resulting in negligible lysis $(0.48$ to $1.4 \%)$ throughout protoplast preparation (Table 1).

Protoplast lysis and membrane preparation. The efficiency of protoplast disruption was investigated by four different lysis procedures (osmotic and detergent shocks, sonic oscillation, freeze-thawing) in either hypotonic (without PEG) or hypertonic (15\% PEG) Tris-buffer (Table 2). The lysates were centrifuged at $200000 \mathrm{~g}$ for $30 \mathrm{~min}$ at $4{ }^{\circ} \mathrm{C}$ and the percentage of lysis was calculated from the amount of $\left[{ }^{3} \mathrm{H}\right]$ thymidine radioactivity found in the supernatant fraction compared to that found in untreated protoplasts. Addition of $2 \% \mathrm{SDS}$ or $0.5 \mathrm{M}-\mathrm{NaCl}$ to hypotonic Tris-buffer resulted in maximal lysis and a $90 \%$ release of $\left[{ }^{3} \mathrm{H}\right]$ thymidine from the cells (Table 2). However, SDS is known to solubilize most membranes (Moldow et al., 1972; Helenius \& Simons, 1975) and hence $\mathrm{NaCl}(0.5 \mathrm{M})$ in hypotonic buffer was the method of choice.

After DNAase and RNAase treatment of the lysates, membranes were collected by centrifugation at $200000 \mathrm{~g}\left(30 \mathrm{~min}\right.$ at $\left.4{ }^{\circ} \mathrm{C}\right)$, and purified on a glycerol cushion.

Analysis of membranes for purity and biological activity. Each membrane preparation from $S$. sanguis was analysed for contamination by either cell wall or cytoplasmic constituents. Radioactive DAP represented only $0.5 \%$ of the original whole-cell radioactivity (Table 1 ). The nucleic acid content of the membranes, determined either by thymidine-incorporated radioactivity or by fluorimetry, represented $1 \%$ and $0 \cdot 17 \%$ of total cell DNA respectively. The total membrane 


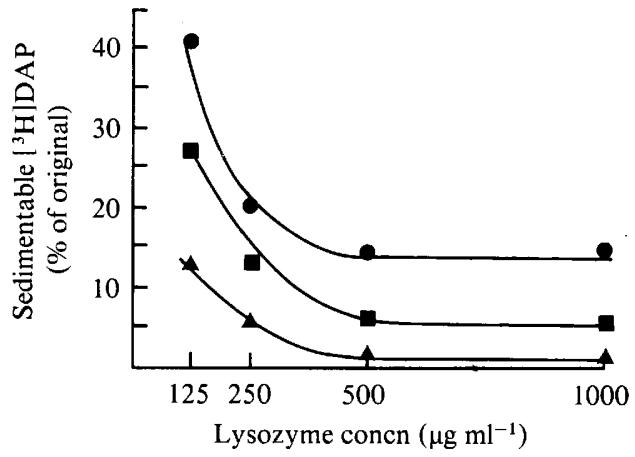

Fig. 1. Effect of various amounts of lysozyme, plasmolysis and swirling on lysozyme-induced protoplast formation. Remaining cell wall associated $\left[{ }^{3} \mathrm{H}\right] \mathrm{DAP}$ radioactivity was measured in the sedimented cells after incubation of bacteria for $1 \mathrm{~h}$ at $30^{\circ} \mathrm{C}$ with various amounts of lysozyme in Trisbuffer supplemented with $6 \%$ PEG, without plasmolysis $(O)$, with plasmolysis $(\square)$ or with plasmolysis and swirling (A).

Table 1. Degree of lysis and cell wall contamination during preparation of protoplasts and membranes from $S$. sanguis

Successive treatments

Plasmolysis (2 h)

Incubation with lysozyme $(1 \mathrm{~h})$

Swirling (1 h)

Lysis $(0 \cdot 5 \mathrm{M}-\mathrm{NaCl})$

Cytoplasmic membrane preparations

$$
\begin{gathered}
\text { Percentage }(w / v) \\
\text { of PEG } \\
\text { in Tris-buffer }
\end{gathered}
$$

$\begin{array}{rc}12 & 0.48 \\ 6 & 1.40 \\ 6 & 1.37 \\ 0 & 92 \\ 0 & -\end{array}$

$$
\begin{gathered}
\begin{array}{c}
\text { Residual cell } \\
\text { wall DAP† } \\
(\%)
\end{array} \\
100 \\
5.1 \\
1.45 \\
- \\
0.52
\end{gathered}
$$

* The percentage of lysis was calculated as the fraction of total $\left[{ }^{3} \mathrm{H}\right]$ thymidine radioactivity found in the supernatant of samples at the end of each treatment per $\mathrm{OD}_{540}$ unit.

$\dagger$ The percentage of cell wall contamination was measured as the fraction of total $\left[{ }^{3} \mathrm{H}\right] \mathrm{DAP}$ radioactivity found in the pellet of samples at the end of each treatment per $\mathrm{OD}_{540}$ unit.

Table 2. Efficiency of different methods of protoplast lysis in either hypotonic or hypertonic medium

\section{Method of lysis}

$\operatorname{SDS}(2 \%, \mathrm{w} / \mathrm{v})$

$\mathrm{NaCl}(0 \cdot 5 \mathrm{M})$

Freeze-thawing

Sonic oscillation

Resuspension in $1 \mathrm{M}$-phosphate buffer $\mathrm{pH} 7 \cdot 2$

$\overbrace{\begin{array}{c}\text { In hypotonic medium } \\ \text { (Tris-buffer) }\end{array}}^{\text {Lysis* of protoplasts }(\%)} \underbrace{\text { I }}_{\begin{array}{c}\text { In hypertonic medium } \\ \text { (Tris-buffer }+15 \% \text { PEG) }\end{array}}$

$\begin{array}{rr}91 & 99 \\ 92 & 50 \\ 6 & 8 \\ 6 & 7 \\ 33 & 33\end{array}$

* The percentage of lysis is calculated as the fraction of total $\left[{ }^{3} \mathrm{H}\right]$ thymidine radioactivity found in the supernatants.

fraction also contained less than $1 \%$ of the glucose-6-phosphate dehydrogenase, a cytoplasmic marker enzyme (Osborn et al., 1972) present in intact protoplasts.

The activity of ATPase, a membrane enzyme (Salton, 1974), was measured to determine whether the procedure used in membrane purification released membrane-associated enzymes. No ATPase activity was found in the different supernatants during protoplast formation. The $S$. sanguis membrane fractions contained 1.7 units of ATPase activity [66.6\% of total activity, 

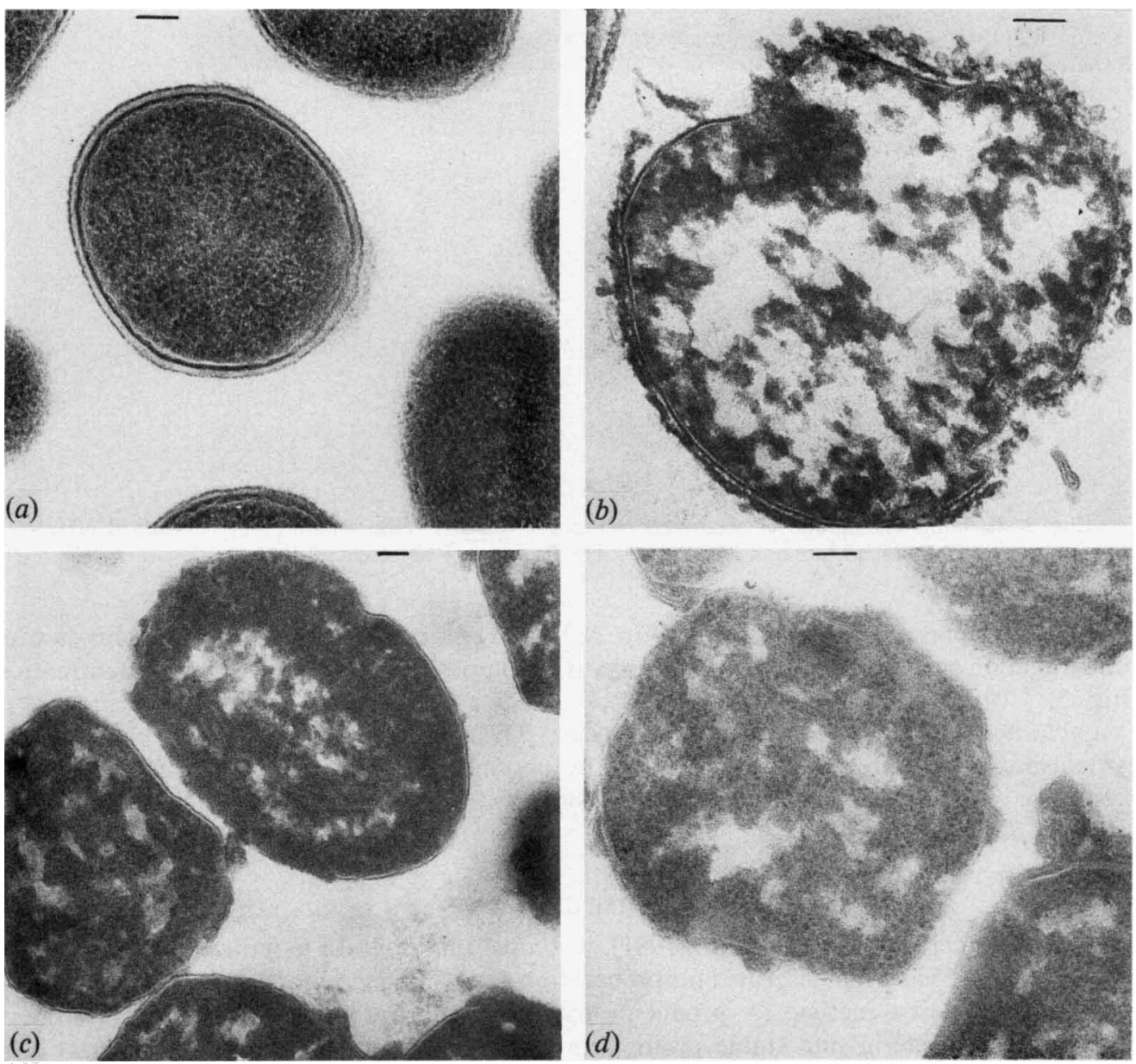

Fig. 2. Electron micrographs of thin sections of S. sanguis OMZ9 after different treatments. (a) Control bacteria; (b) cells after treatment for $1 \mathrm{~h}$ with lysozyme $\left(500 \mu \mathrm{g} \mathrm{ml}^{-1}\right) ;(c)$ cells prior to lysozyme treatment but after plasmolysis $\left(2 \mathrm{~h}\right.$ at $30{ }^{\circ} \mathrm{C}$ in presence of $\left.12 \% \mathrm{PEG}\right) ;(d)$ cells after plasmolysis, lysozyme treatment and swirling $\left(1 \mathrm{~h}\right.$ at $30^{\circ} \mathrm{C}$ in presence of $\left.6 \% \mathrm{PEG}\right)$. Progressive solubilization of the cell wall occurred during the above mentioned treatments and a typical protoplast apparently devoid of cell wall material can be seen in $(d)$. The bar markers represent $0.1 \mu \mathrm{m}$.

specific activity $0 \cdot 2$ units $(\mathrm{mg} \text { protein })^{-1}$ ] whereas 0.6 units $\left(23.8 \%, 0.0012\right.$ units $\left.\mathrm{mg}^{-1}\right)$ was found in the cytoplasmic fraction, and 0.24 units $(9.5 \%)$ in the different membrane washes, indicating that rather low release of enzyme occurred during this procedure.

Chemical analysis of the membranes. The results of the gross chemical analysis of $S$. sanguis cytoplasmic membranes are expressed as percentages of the total dry weight of membranes. Total protein accounted for $62 \%$ of the membrane preparation. Total lipids comprised $20 \%$ of the dry weight, with a phosphorus/lipid ratio of 0.045 . Total hexose content of the membrane was relatively low, representing only $4.2 \%$, which agrees with the work of others (Owen \& Freer, 1972; Van de Rijn \& Kessler, 1979).

Electron microscopy. All steps in protoplast and membrane preparations were further followed by electron microscopy to confirm the effectiveness of the method. Figure 2 illustrates the different stages in protoplast formation after $1 \mathrm{~h}$ incubation in the reaction mixture with lysozyme alone (Fig. $2 b$ ), with preliminary plasmolysis (Fig. $2 c$ ), and with additional swirling (Fig. $2 d$ ). While initially the streptococci had a typical cell wall (Fig. 2a), progressive elimination of wall material was seen after the different treatments, and wail contamination was 


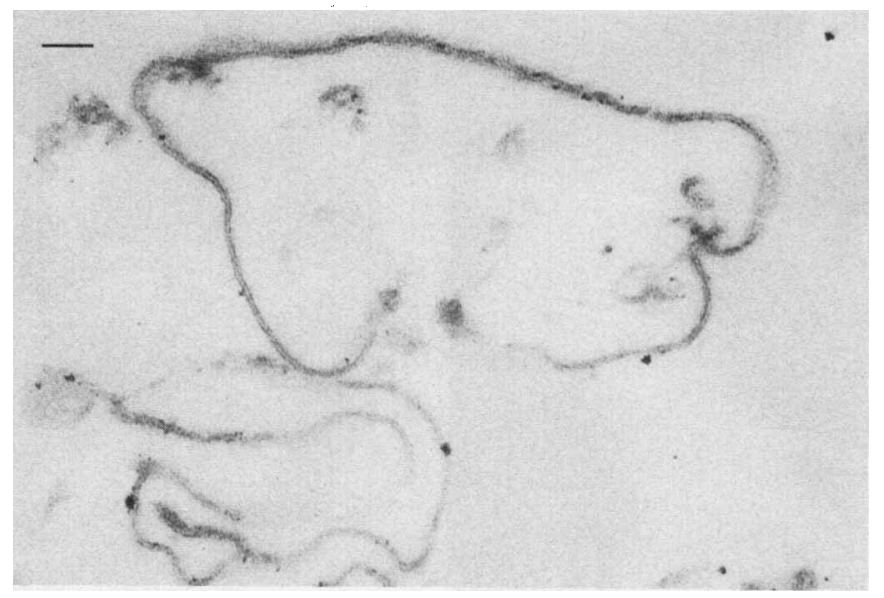

Fig. 3. Electron micrograph of a puritied membrane fraction. Thin sections were examined after staining with uranyl acetate and lead citrate. The bar marker represents $0 \cdot 1 \mu \mathrm{m}$.

minimal after plasmolysis and swirling (Fig. $2 d$ ). Thin sections of cytoplasmic membranes after centrifugation on a glycerol cushion appeared to be completely devoid of cell wall contamination (Fig. 3).

Application of the method to other serotypes. The results described above showed that cytoplasmic membrane preparations could be obtained from $S$. sanguis OMZ9. The same procedure, outlined in Fig. 4, was successfully used to obtain cytoplasmic membranes from different $S$. mutans serotypes.

\section{DISCUSSION}

With the exception of Siegel et al. (1981), who used mutanolysin to induce spheroplasts, no suitable method has been described for preparation of plasma membranes from $S$. sanguis or $S$. mutans. We report a method for producing membranes from these species by a preliminary conversion of bacteria into stable protoplasts with lysozyme. Acetylation of bacterial cells according to Eisenberg \& Lillmars (1975) did not provide any advantage in protoplast formation (data not shown). In order to enhance lysozyme sensitivity, bacteria from exponential phase cultures grown in the presence of DL-threonine (Chassy, 1976) were diluted in Tris/ $\mathrm{HCl}$ buffer (Witholt \& Boekhout, 1978) supplemented with PEG (Owen \& Freer, 1972). After determination of optimal concentrations of lysozyme $\left(500 \mu \mathrm{g} \mathrm{ml}^{-1}\right)$ and PEG $(6 \%)$, we tested the effect of plasmolysis and swirling on the efficiency of protoplast formation. Exposure of cells to $12 \%$ PEG increased their sensitivity to lysozyme and increased the yield of protoplasts. This was further improved by a swirling step after PEG dilution. Chemical and ultrastructural studies indicated the almost complete lack of cell wall material in the protoplast preparations. Addition of $0.5 \mathrm{M}-\mathrm{NaCl}$ to osmotically sensitive protoplasts suspended in hypotonic Tris-buffer resulted in up to $90 \%$ lysis, and membranes prepared in this way contained only a small amount of the peptidoglycan DAP. This method allowed us to prepare cytoplasmic membranes from the different $S$. mutans serotypes.

The gross chemical composition of $S$. sanguis cytoplasmic membranes appeared to be in broad agreement with that reported by Kessler \& Van de Rijn (1979). Contamination of the membranes by either extracellular or intracellular components was less than $1 \%$, as estimated by the peptidoglycan or DNA content, and the protein/phospholipid ratio was in accord with those generally found for Gram-positive bacteria (Owen \& Freer, 1972; Van de Rijn \& Kessler, 1979).

It should be pointed out that the above results are drawn from membranes with minor cytoplasmic or wall contamination. The enzyme treatment and washing steps do not appear to affect the integrity of the membranes, which can be compared to membranes obtained by other methods (Siegel et al., 1981). 
Washed cells (grown in BHI containing $20 \mathrm{mM}$-DL-threonine)

Plasmolysis (Tris/ $\mathrm{HCl}, 10 \mathrm{mM}, \mathrm{pH} 7 \cdot 2$ ['Tris-buffer'] containing $\left.12 \%(\mathrm{w} / \mathrm{v}) \mathrm{PEG}, 2 \mathrm{~h}, 30^{\circ} \mathrm{C}\right)$

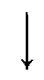

Protoplast formation (lysozyme, $500 \mu \mathrm{g} \mathrm{ml}^{-1}, 1 \mathrm{~h}, 30^{\circ} \mathrm{C}$ )<smiles>[Tl]</smiles>

Swirling (dilution with 1 vol. Tris-buffer, $1 \mathrm{~h}, 30^{\circ} \mathrm{C}$ )

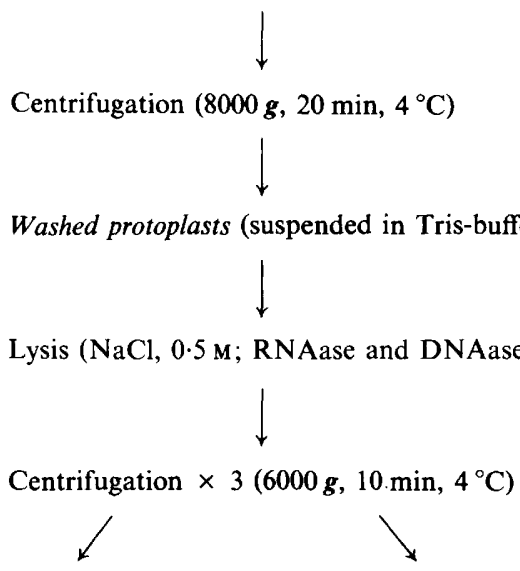

Pellet (discard)

Supernatant containing cytoplasmic membranes

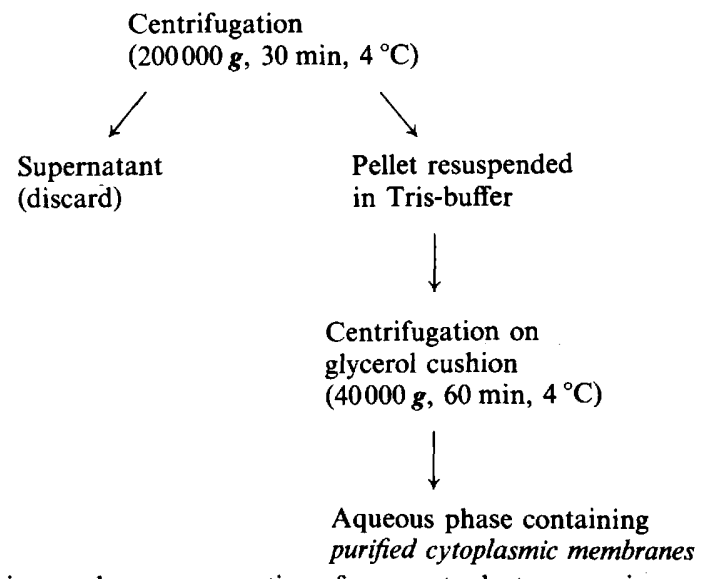

Fig. 4. Procedure used to obtain cytoplasmic membrane preparations from protoplast suspensions.

We thank Mrs A. Pini for expert technical assistance.

\section{REFERENCES}

ABrams, A. (1965). The release of bound adenosine triphosphatase from isolated bacterial membranes and the properties of the solubilized enzyme. Journal of Biological Chemistry 240, 3675-3681.
BAGINSKI, E. S. \& ZAK, B. (1960). Microdetermination of serum phosphate and phospholipids. Clinica chimica acta 5, 834-838.

Beighton, D., Russell, R. R. B. \& Hayday, $H$. 
(1981). The isolation and characterization of Streptococcus mutans serotype $h$ from dental plaque of monkeys (Macaca fascicularis). Journal of General Microbiology 124, 271-279.

Bleiweis, A. S. \& ZimmermanN, L. B. (1961). Formation of two types of osmotically fragile bodies from Streptococcus faecalis var. liquefaciens. Canadian Journal of Microbiology 7, 363-373.

BRATTHALL, D. (1970). Demonstration of five serological groups of streptococcal strains resembling Streptococcus mutans. Odontologisk revy 21, 143-152.

Calandra, G. B., Nugent, K. M. \& Cole, R. M. (1975). Preparation of protoplasts of group $\mathbf{H}$ streptococci (Streptococcus sanguis). Applied Microbiology 29, 90-93.

Chassy, B. M. (1976). A gentle method for lysis of oral streptococci. Biochemical and Biophysical Research Communications 68, 603-608.

Chiu, T. H., Emdur, L. I. \& Platt, D. (1974). Lipoteichoic acids from Streptococcus sanguis. Journal of Bacteriology 118, 471-479.

Coleman, S. E., Van de RiJn, I. \& Bleiweis, A. S. (1970). Lysis of grouped and ungrouped streptococci by lysozyme. Infection and Immunity 2, 563-569.

Coykendall, A. L. (1974). Four types of Streptococcus mutans based on their genetic, antigenic and biochemical characteristics. Journal of General Microbiology 83, 327-338.

Dulley, J. R. \& Grieve, P. A. (1975). A simple technique for eliminating interference by detergents in the Lowry method of protein determination. Analytical Biochemistry 64, 136-141.

EISENBERG, R. J. \& LillmaRs, K. (1975). A method for gentle lysis of Streptococcus mutans. Biochemical and Biophysical Research Communications 65, 378-384.

FormaneK, H., FormaNEK, S. \& WAWRa, H. (1974). A three dimensional atomic model of the murein layer of bacteria. European Journal of Biochemistry 46, 279-294.

Gibbons, R. J., De Stoppelaar, J. D. \& Harden, L. (1966). Lysozyme insensitivity of bacteria indigenous to the oral cavity of man. Journal of Dental Research 45, 877-881.

Goodman, H., Pollock, J. J., Katona, L. I., Iacono, V. J., Сно, М. I. \& Thomas, Е. (1981). Lysis of Streptococcus mutans by hen egg white lysozyme and inorganic sodium salts. Journal of Bacteriology 146, 764-774.

GugGenHEIM, B. (1968). Streptococci of dental plaque. Caries Research 2, 147-163.

Hayashi, H., Araki, Y. \& ITo, E. (1973). Occurrence of glucosamine residues with free amino groups in cell wall peptidoglycan from bacilli as a factor responsible for resistance to lysozyme. Journal of Bacteriology 113, 592-598.

Helenius, A. \& Simons, K. (1975). Solubilization of membranes by detergents. Biochimica et biophysica acta 415, 29-79.

Johnston, K. H. \& Gotschlich, E. C. (1974). Isolation and characterization of the outer membrane of Neisseria gonorrhoeae. Journal of Bacteriology 119, 250-257.

Joseph, R. \& Shockman, G. D. (1975). Cellular localization of lipoteichoic acid in Streptococcus faecalis. Journal of Bacteriology 122, 1375-1386.

KESSLER, R. E. \& VAN DE RIJN, I. (1979). Quantitative immunoelectrophoretic analysis of Streptococcus pyogenes membrane. Infection and Immunity 26, 892902.

KRAUSE, R. M. (1972). The antigens of group D streptococci. In Streptococci and Streptococcal Diseases, pp. 67-74. Edited by L. W. Wannamaker \& J. M. Matsen. New York: Academic Press.

MaRKhaM, J. L., KNoX, K. W., WiCKen, A. J. \& HeweTt, M. J. (1975). Formation of extracellular lipoteichoic acid by oral streptococci and lactobacilli. Infection and Immunity 12, 378-386.

Moldow, C., RoberTson, J. \& RothField, L. (1972). Purification of bacterial membrane proteins. The use of guanidium thiocyanate and urea. Journal of Membrane Biology 10, 137-152.

MORRIS, D. L. (1948). Quantitative determination of carbohydrates with Dreywood's anthrone reagent. Science 107, 254-256.

Osborn, M. J., Gander, J. E., Parisi, E. \& Carson J. (1972). Mechanism of assembly of the outer membrane of Salmonella typhimurium. Journal of Biological Chemistry 247, 3962-3972.

OWEN, P. \& FREer, J. H. (1972). Isolation and properties of mesosomal membrane fractions from Micrococcus lysodeikticus. Biochemical Journal 129, 907-917.

Perch, B., KJems, E. \& Ravn, T. (1974). Biochemical and serological properties of Streptococcus mutans from various human and animal sources. Acta pathologica et microbiologica scandinavica B, 82, 357370.

Pollock, J. J., Iacono, V. J., Goodman Bicker, H., Mackay, B. J., Katona, L. I., Taichman, L. B. \& Thomas, E. (1976). The binding, aggregation and lytic properties of lysozyme. In Proceedings, Microbial Aspects of Dental Caries, vol. 2, pp. 325-352. Edited by H. M. Stiles, W. J. Loesche \& T. C. O'Brien. Special supplement to Microbiology $A b$ stracts. Washington, D.C.: Information Retrieval.

Russell, M. W. \& LehNER, T. (1978). Characterization of antigens extracted from cells and culture fluids of Streptococcus mutans serotype $c$. Archives of Oral Biology 23, 7-15.

Russell, R. R. B. (1979). Wall-associated protein antigens of Streptococcus mutans. Journal of General Microbiology 114, 109-115.

SAlton, M. R. J. (1974). Membrane associated enzymes in bacteria. Advances in Microbial Physiology 11, 213-282.

Schöller, M., Klein, J. P. \& Frank, R. M. (1981). Common antigens of streptococcal and non-streptococcal oral bacteria: immunochemical studies of extracellular and cell-wall associated antigens from Streptococcus sanguis, Streptococcus mutans, Lactobacillus salivarius and Actinomyces viscosus. Infection and Immunity 31, 52-60.

ShKLAIR, I. L. \& KeENE, H. J. (1976). Biochemical characterization and distribution of Streptococcus mutans in three diverse populations. In Proceedings, Microbial Aspects of Dental Caries, vol. 1, pp. 201210. Edited by H. M. Stiles, W. J. Loesche \& T. C. O'Brien. Special Supplement to Microbiology $A b$ stracts. Washington, D.C.: Information Retrieval.

Shockman, G. D., Daneo-Moore, L., Cornett, J. B. \& MychaJlonka, M. (1979). Does penicillin kill bacteria? Reviews of Infectious Diseases 1, 787-796. 
Siegel, J. L., Hurst, S. F., Liberman, E. S., Coleman, S. E. \& BLeIWEIS, A. S. (1981). Mutanolysin-induced spheroplasts of Streptococcus mutans are true protoplasts. Infection and Immunity 31, 808-815.

Silvestri, L. J., Craig, R. A., Ingram, L. O., HoffmanN, E. M. \& Bleiweis A. S. (1978). Purification of lipoteichoic acid by using phosphatidyl choline vesicles. Infection and Immunity 22, $107-$ 118.

SMith, D. G. (1973). The lysozyme sensitivity of Streptococcus equinus. Microbios 8, 199-207.

TAuBMAN, M. A. (1973). Role of immunization in dental disease. In Comparative Immunology of the Oral Cavity, pp. 138-158. Edited by S. E. Mergenhagen \& H. W. Sherp. Washington, D.C.: U.S. Government Printing Office.
Thomas, P. S. \& Farquhar, M. N. (1978). Specific measurement of DNA in nuclei and nucleic acids using diaminobenzoic acid. Analytical Biochemistry 89, 35-44.

VAN DE Rijn, I. \& Kessler, R. E. (1979). Chemical analysis of changes in membrane composition during growth of Streptococcus pyogenes. Infection and Immunity 26, 883-891.

Vaught, R. M. \& Bleiweis, A. S. (1974). Antigens of Streptococcus mutans. II. Characterization of an antigen resembling a glycerol teichoic acid in walls of strain BHT. Infection and Immunity 9, 60-67.

Witholt, B. \& BoEkhout, M. (1978). The effect of osmotic shock on the accessibility of the murein layer of exponentially growing Escherichia coli to lysozyme. Biochimica et biophysica acta 508, 296-305. 